\title{
Exploration of Talent Cultivation Models of Industrial Colleges Under the Background of "New Engineering"
}

\author{
Xuehua Jiang ${ }^{1, *}$, Peijiang Chen ${ }^{2}$ \\ ${ }^{1}$ School of Automation and Electrical Engineering, Linyi University, Linyi, China \\ ${ }^{2}$ School of Mechanical and Vehicle Engineering, Linyi University, Linyi, China \\ "Corresponding author. Email: jxhyx @ 163.com
}

\begin{abstract}
Based on the concept of "new engineering" construction, schools and enterprises jointly build and co-manage industrial colleges, strengthening school-enterprise cooperation, deepening the integration of industry and education, and focus on the education concept and training mechanism, organizational structure and management system, practice curriculum system and practical teaching innovation, etc.. By exploring the talent cultivation models of industrial colleges under the Background of "New Engineering", the universities and colleges can cultivate applied talents meeting the society need.
\end{abstract}

Keywords: New engineering, Industrial College, School-enterprise cooperation, Integration of production and education, Talent training model.

\section{INTRODUCTION}

The existing engineering education of local colleges and universities has many kinds of incompatibility with the needs of industry development in terms of school positioning and connotation development, talent training system, school-enterprise interaction mechanism, discipline construction, training mechanism, school governance system, etc., which requires universities to further deepen education reform, build a integration model of production and education, and schoolenterprise collaborative education. In the construction context of "new engineering", how to promote university organizational innovation and explore new models of school-enterprise cooperation [1].

As a product of the multi-party collaborative education model under the background of "new engineering", the industrial college has innovated the depth, breadth and intensity of school-enterprise cooperation, allowing high-quality corporate resources to participate in the training of talents in colleges and universities, and deepening the collaborative education of industry-university cooperation [2].

The latest demands of industry and technology development promote the reform of talent training in colleges and universities. Therefore, the integration of industry and education is the basic connotation of "new engineering", and the joint construction of industry colleges by schools and enterprises is a new model for deepening the integration of industry and education [3].

Practice has shown that schools, especially engineering colleges and universities, the running level and the quality of talent training depend to a large extent on whether they have a high-level production-education integration model. The primary goal of the industrial college is to cultivate applied talents with strong practical ability.

\section{SCHOOL-ENTERPRISE CO- CONSTRUCTION OF INDUSTRIAL COLLEGE COOPERATION MODEL}

Industry-education integration and school-enterprise cooperation can only be realized by relying on a certain organizational form. In the context of the rapid development of "new engineering", industrial colleges have become an effective new organizational form, providing organizational guarantees for the transformation of local undergraduate colleges, and promoting reform of the system and mechanism of school-enterprise cooperation, integration of production and education [4]. 
The cooperation model of industrial colleges must first establish the governance structure and management system to ensure the smooth operation. The board of directors is composed of personnel from both schools and enterprises, which aims to promote the integration, school-enterprise cooperation and education, and promote the council constitution. The industrial college implements the dean responsibility system under the leadership of council and is implemented in accordance with the operation and management system. The dean and deputy deans of the industrial college are assumed by the school and the industry, and are mainly responsible for coordinating resources of all parties and organizing forces to implement the resolutions of the council.

By taking advantage of the school's high-level talents' high level of knowledge, establishing a schoolenterprise teacher-sharing and co-education mechanism can enhance the theoretical level of enterprise teachers. By giving full play to the technical leadership role of corporate professionals, the practical ability and practical teaching level of professional teachers are effectively improved, and a "dual-teacher dual-capable" faculty team is created to achieve the optimization and integration of university resources and social resources [5].

Through the establishment and management of industrial colleges, both schools and enterprises build a long-term mechanism for the integration of industry and education and a win-win situation for schools and enterprises, realize the integration of work and learning in the whole process of teaching and research, build a benign and interactive operating mechanism for schoolenterprise cooperation, realize the integrated ecological development of, and promote the construction of "new engineering" , to train the talents needed for the transformation and upgrading of regional industries.

\section{THE PROFESSIONAL CO- CONSTRUCTION MODEL OF THE INDUSTRIAL COLLEGE}

As a talent training community that complements the advantages of schools and enterprises, and win-win benefits, industrial colleges should give full play to their respective advantages and undertake the construction of different types of courses in the process of professional construction. Both schools and enterprises are guided by regional industry needs, driven by innovation, and follow the law of the development of engineering education to jointly build specialties that integrate industry and education.

The school and enterprise jointly establish a professional construction steering committee, which is mainly composed of professional and technical leaders, guides and implement relevant cooperation content in the integration of production and education, schoolenterprise cooperation talent training model, professional construction planning, formulation and revision of talent training programs, and curriculum construction and development. The professional construction steering committee has established a school-enterprise collaboration talent training plan formulation and update mechanism.

Firstly, analyze the demand for professional talents in industrial development under the background of the new economy, sort out the needs of typical industry positions for talent knowledge, ability and literacy, jointly determine the direction of professional training, and design a curriculum system that meets the needs of the industry. Secondly, both school and enterprise summarize and analyze the talent training plan in the links of teaching implementation, assessment and evaluation, and student employment.

At the same time, according to the needs of industry development, the talent training plan is revised and updated on a regular basis. Both schools and enterprises are responsible for the teaching tasks of different types of courses according to their respective advantages. The full-time teachers of the school are mainly responsible for general and public basic courses, professional basic courses and vocational elective courses while corporate part-time teachers are mainly responsible for professional core courses and practical courses, including comprehensive semester special practice, primary school training, guidance for corporate internships, Graduation design, etc.

\section{COLLABORATIVE TRAINING MODEL OF INDUSTRIAL COLLEGES}

The construction of "new engineering" is conducive to promoting the reform of the undergraduate talent training model. The focus of the reform of the talent training model is to build majors for industry needs, deepen the reform of teaching content and teaching system, and promote the integration of production and education. The construction of industrial colleges should deepen the CDIO talent training model, and create a characteristic engineering education model of theory, practice, projects, innovation, and entrepreneurship in a project-driven way [6].

The school-enterprise collaborative talent training model is a talent training model, which is based on the international engineering education models of OBE and 
CDIO, based on the stage theory of professional ability development and the experience-oriented learning theory of network structure, combined with industry and education experience.

Through the expression form of "converting projects into teaching cases", the teaching form of "training + internship", and the teaching method of "learning by doing, doing while learning", the actual industry experience and needs are passed to education, and the whole training process of integration of industry and education is guided, realization docking of professional setting and industry needs, course content and professional standards, teaching process and production process, graduation certificate and vocational qualification certificate, vocational education and lifelong learning, and finally to realize "industry to promote education, education to promote industry". According to the needs of industry talents, schoolenterprise collaborative education is generally divided into 4 stages.

\subsection{Stage 1}

Skills reserve stage (5 semesters before undergraduate). The overall emphasis is on "learning" and task-driven. Focus on improving the "static structure" of knowledge to "dynamic transformation". The training goal at this stage is to enable students to have a complete engineering knowledge system, master the application of common knowledge points in project development, and have a certain degree of standardization and proficiency in engineering development.

\subsection{Stage 2}

Simulation training phase (the 6th semester of undergraduate). The overall emphasis is on "practice" and case-driven. Focus on ensuring the integrity of case projects. The training goal at this stage is to enable students to have project engineering ideas, be able to complete work tasks according to the division of labor, and have the skills requirements for relevant positions in the enterprise.

\subsection{Stage 3}

Position training stage (undergraduate semester 7 and 8). The overall emphasis is on real "doing" and project-driven. Focus on ensuring the completion of the delivery of real industrial projects. The training goal at this stage is to enable students to have comprehensive skills, independent thinking and problem-solving abilities, and project innovation abilities to be competent in project development-related positions.

\subsection{Stage 4}

Employment internship stage (undergraduate semester 8). The overall emphasis is on "employment, combination of learning and doing", job-driven. Focus on ensuring employment exports, corresponding to junior talents. At this stage, it is mainly oriented to the job requirements of the industry, and targeted project enhancement training is carried out. The goal of training is to make students become industry and talents needed.

\section{ESTABLISHMENT OF PRACTICAL TEACHING ENVIRONMENT AND IMPLEMENTATION OF PRIMARY SCHOOL TRAINING}

According to the school-enterprise collaborative talent training model, semester training, comprehensive training, and corporate internships will be systematically designed according to the academic year, to realize the whole process of vocational skills training. Realize knowledge integration through semester training, realize skill integration through comprehensive training, and realize job integration through enterprise internship. The interterm training is mainly arranged in summer and winter vacations. There are 6 interterms in 4 years for undergraduates [7].

A practical curriculum system based on the integration of production and education. The purpose of interterm training is to enable students to comprehensively use the professional theoretical knowledge of this semester, design training projects, decompose tasks in stages, realize a complete real project and solve practical problems in the training process, and help students consolidate and expand theoretical knowledge, improve professional practical skills, exercise the ability to analyze and solve problems.

\subsection{Training mode}

For the purpose of completing the project, learning by doing, doing while learning, and learning by doing. In addition to cultivating students' professional abilities, practical training also runs through the training of students' sense of teamwork, time management, selfawareness, stress resistance, communication skills, selfpromotion ability, master interview skills and interview etiquette, in order to improve professional skills, professional quality, professional awareness, and gradually realize the transition to a "professional".

\subsection{Training procedures}

Adopting the "quasi-employee" management method and training mode, in accordance with the implementation process of entry $\rightarrow$ team formation $\rightarrow$ 
job assignment, project implementation $\rightarrow$ project acceptance, students are allowed to conceive $\rightarrow$ design $\rightarrow$ realize $\rightarrow$ run (CDIO) during the implementation of the project. Let students learn and acquire engineering skills in an active, practical, and organic way between courses.

\subsection{Training characteristics}

Provide real office environment, projects, project managers, project pressures, and job opportunities, strengthen the cultivation of students' comprehensive ability and professionalism, and use case teaching to improve students' self-learning and practical ability, examine and evaluate students from multiple angles to help students solve the real problem.

\subsection{Basic training situation}

The curriculum design of the entire training project adopts a step-by-step approach to cover the needs of students at different levels. The basic stage mainly talks about basic knowledge, the actual combat stage mainly practices basic functions (general technology), and the skill improvement stage mainly focuses on the practice of extended functions (frontier technology). During the entire production training process, the project team can follow the trainees' situation and the progress of the project.

\subsection{Training assessment}

The student's assessment results are composed of group assessment and individual assessment results, each accounting for $50 \%$. Group assessment indicators mainly include project establishment, demand investigation and analysis, outline design, detailed design, daily project management, etc., mainly through the inspection method of walkthrough and review. Personal assessment indicators mainly include the mastery of technical concepts, work habits, and occupation literacy and ethics, innovation and research, mainly through examinations, walkthroughs and assessments.

Through the real engineering environment, the introduction of cutting-edge technology, and the use of quasi-employee management methods and training models, improve students' engineering literacy, professionalism, innovation ability, critical thinking, independent learning ability, communication and negotiation ability, engineering leadership, etc.

\section{CONCLUSIONS}

As a new path of school-enterprise cooperation, the school of Industry has established an enterprise-led open and socialized school-running model, and constructed a learning model of "learning-while training-re-learning- re-training", which can realize project teaching, case teaching, production process-oriented teaching methods, establish a professional and combined diversified "dualteacher" professional teacher team, and build an industry demand-oriented employment supply and demand system.

The industrial academy cooperation model based on the integration of industry and education and collaborative education is of great significance to the realization of "new engineering" talent training, which can boost regional economic and social development, and cultivate a compound excellent project with innovative capabilities for emerging industries and the new economy talent.

\section{ACKNOWLEDGMENTS}

This study was supported by the Education Project of Industry-university Collaboration of the Ministry of Education in 2017 (No. 201702141001) and in 2019(No. 20190215034), the First-class Undergraduate Course Construction Project of Shandong Province in 2019 (Automobile Theory), the Undergraduate Teaching Reform Project of Shandong Province Higher Education in 2018 (No. M2018X062) and in 2020(No. Z2020072), the specific subject of China Association of Higher Education in 2021(No. 21ZJD30) and the Teaching Quality Engineering Projects of Linyi University in 2018 and 2020.

\section{REFERENCES}

[1] Xinqiao Liu. "Emerging Engineering Education, Integration of Production and Education and Industrial Transformation and Upgrading," Higher Vocational Education Exploration, vol. 7, no. 1. Pp. 1-4, 2018.

[2] Fenghong Wang. "Research on the Path and Mechanism of Collaborative Education in Industrial College-Take Caibai Business College of Beijing College of Finance and Commerce as an Example," Journal of Beijing College of Finance and Commerce, vol. 37, no. 3, pp. 39-43, 2021.

[3] Weihong Zhu, Yunfei Peng. "Research on the construction of industrial college in local undergraduate colleges and universities under the background of new engineering," Journal of Higher Education Management, vol. 12, no. 2, pp. 30-37, 2018

[4] Peijiang Chen, Mei Zhagn, Hu Han, Xiao Mi, Xiangke Tian. "Research and practice of fivedimensional practice platform construction for mechanical major," Asia-Pacific Education, no. 1, pp. 138-139, 2021. 
[5] Daqian Huang, Lijuan Rao, "Construction of Symbiotic Industrial College in Applicationoriented Universities and Practice in Guangdong," Journal of National Academy of Education Administration, no. 6, pp. 45-51, 2021.

[6] Xuehua Jiang, Peijiang Chen. "A Study on the Mode of Talent Cultivation for the New Engineering Development in Local Universities," Journal of Linyi University, vol. 40, no. 6, pp. 108117, 2018.

[7] Xinge Jiang. "The School of Industry: Analytical Reflection and Practice," Journal of Guangdong Industry Polytechnic, vol. 20, no. 1, pp. 39-44, 2021. 